consists of the president, vice-president, and secretary. There is no question, however, that the formation of the catalogues will always form one of the great objects of the association, and its publication wiil absorb a material fraction of its funds.

One of the subjects discussed at the meetings was the study and origin of small periodic disturbances, some of which have short periods of 6 to II seconds, or the somewhat longer period of 30 seconds. The latter seem to occur when strong winds sweep over a country, but no connection of the former with meteorological occurrences has been proved, and the only suggestion of a rational explanation is that due to Prof. Wiechert, who believes them to be due to the impact of ocean waves on the shores. A small committee was appointed to investigate the question, and a sum of $50 l$. was placed at its disposal. Prof. Omori, who had independently expressed the wish to investigate this matter, was also granted a sum of $50 l$. to carry out his investigations.

Another committee was appointed to report on the question of preparing a complete annual index of the literature of the subject. The committee was instructed to enter into communication with the International Catalogue and the "Office international de Bibliographie," in order to ascertain whether one of the existing organisations may be utilised for the purpose.

According to a resolution arrived at in Rome in October, I906, the president of the association vacates his office on April I following the general meetings, which, as a rule, take place every four years. The permanent committee had therefore to elect a new president; Prof. Palazzo, who has held the office during the last year, not being re-eligible, a ballot was taken, and Prof. Arthur Schuster received the majority of votes. In thanking the meeting for the honour bestowed upon him, and accepting the office, Prof. Schuster said that he was not an expert on seismological questions, but considered it to be his duty to accept the position, as he considered that it was intended as a recognition of the services rendered by Great Britain, and notably by Prof. Milne, not only in originating the scientific study of earthquakes, but also in first organising combined observations on an international basis. Prof. Forel, of Lausanne, who is well known through his work on seiches, was elected vice-president.

The general meeting was opened on the morning of September 24 by a speech of the Minister of the Colonies, and the two succeeding days were taken up in great part by addresses on various subjects connected with seismology. Of special interest were the account given by Prince Galitzin of his seismometric studies, and a paper by Prof. Wiechert on the utilisation of seismic records towards the investigation of the physical properties of the earth.

It was-the duty of the general meeting to fix the locality of the central bureau, and it was resolved to retain Strassburg for the next period of four years.

The delegates were most hospitably entertained; an evening entertainment, as well as a dinner, was given by the Minister of the Colonies on behalf of the Government of Her Majesty the Queen, and the meeting concluded with an excursion by boat through some of the characteristic canals and inland lakes of the country. Prof. van der Stok, the vice-president, and his able assistants, Dr. Hartmann, Dr. Romeijn, Mr. Levoir, and Baron van Voorst tot Voorst, must be congratulated on the perfection of the organisation, which more than anything else allowed the meeting to do its work smoothly and effectively. The permanent committee will come together in I909 at some place in Switzerland not yet determined, and the place for the next general meeting in I9I I will then have to be fixed. It was too soon to come to any definite decision, but an informal expression that the meeting might appropriately take place in England seemed to meet with a very general approval.

\section{SIR F. L. MCCLINTOCK, K.C.B., F.R.S.}

A DMIRAL SIR FRANCIS LEOPOLD MCCLINA TOCK, whose death on Sunday last, at eightyeight years of age, we regret to announce, will be remembered so long as the story of polar exploration has any interest for the human race. Fifty years have passed since the Fox, with Sir Leopold (then Captain) McClintock in command, sailed in search of the Franklin expedition, and the fiftieth anniversary of this memorable event was appropriately marked on June 30 last by a letter of congratulation sent to him from the Royal Geographical Society.

Sir Leopold McClintock's Arctic service began in I848, when he accompanied Sir James Clark Ross as second lieutenant on board H.M.S. Enterprise, in the expedition sent out by the Admiralty. Returning unsuccessful in November, I 849 , McClintock joined a second expedition sent out early in 1850 as senior lieutenant of H.M.S. Assistance, with Sir Erasmus Ommanney. It was his fortune in August, $185^{\circ}$, to see, at Cape Riley, the first traces of the missing Franklin expedition. In the following spring, whilst frozen up at Griffith Island, he signalised himself by a remarkable sledge journey of 80 days and 760 geographical miles, reaching the most westerly point which had been attained from the east in the Arctic regions. Upon the return of this expedition to England in October, $185 \mathrm{I}$, he was promoted to the rank of commander; and in the following spring he proceeded to the Arctic regions in command of H.M.S. Intrepid, one of five vessels composing the third searching expedition, under Sir Edward Belcher's command. In accordance with instructions from the Admiralty, the Intrepid, in company with the Resolute, Captain Kellett, wintered at Melville Island, in order to search for Captain McClure and his companions; and, fortunately, they were discovered and rescued, after their three years imprisonment in the ice. McClintock again distinguished himself by his sledge journey of 105 days and 12 Io geographical miles into the hitherto unexplored region northward of Melville Island. The advances which Arctic sledgetravelling has made are almost entirely due to the improvements effected by him. Abandoning four out of the five ships imbedded in the ice, and also McClure's ship, the Investigator, the personnel of this expedition, with McClure and his companions, returned to England in October, 1854 , in the depôt ship North Star, and two relief ships, freshly arrived out, under Captain Inglefield.

In I857 McClintock accepted the command of the search expedition fitted out mostly at Lady Franklin's expense. He selected and equipped the steam-yacht Fox, of I77 tons, and with twenty-four companions sailed on July $I, 1857$. He returned on September 20, I859, having discovered, upon the north-west shore of King William's Island, a record announcing the death of Sir John Franklin and the abandonment of the Erebus and Terror. He brought home intelligence of their discoveries and the fate of their crews, and many relics of the expedition. The story of this voyage was fully related by McClintock himself in "The Voyage of the $F_{O x}$ in the Arctic Seas: a Narrative of the Discovery of the Fate of Sir John Franklin and his Companions," a work which ran through 
many editions, and is a classic story of geographical achievement. In recognition of his services McClintock was knighted, and in $186_{5}$ was elected a Fellow of the Royal Society. He was appointed a K.C.B. in I 89 I.

\section{NOTES.}

IN consequence of numerous reports as to the occurrence of a very serious disease among bees in the Isle of Wight, known locally as "paralysis," the Board of Agriculture and Fisheries instructed Mr. A. D. Imms to undertake an inquiry into the nature and cause of the disease; his report on the result of his investigations has now been issued by the Board in pamphlet form. Fortunately, the geographical distribution of the disease is confined apparently to the Isle of Wight, so that with due precaution there should be little or no fear of its spreading to the mainland apiaries. "The disease is eminently one of the digestive system, and might be described as being a condition of enlargement of the hind intestine." Smears made from the contents of the colon showed large numbers of bacteria, and it is possible that there may be some connection between this disease and the well-known form of "dysentery" in bees. The symptoms are complete loss of flight, crawling aimlessly over the ground or up grass stems and the supports of the hive.

THE cablegrams from America in Monday's papers announced the tragic death of Prof. L. M. Underwood, of Columbia University, New York. His mind had been unhinged by the recent financial crisis, and he committed suicide after killing his wife and attempting to kill his daughter. He was born in New York State in 1853 , and became professor of botany in Columbia University in 1896 . His published works included "Descriptive Catalogue of North American Hepaticæ," "Moulds, Mildews and Mushrooms," "Our Native Ferns and their Allies," and "Our Native Ferns and How to Study Them."

AT the unanimous invitation of the executive committee of the Yorkshire Naturalists' Union, Dr. Wheelton Hind has accepted the presidency of the union for the forthcoming year. Dr. Hind is well known throughout the country for his successful work amongst Carboniferous rocks, and in Yorkshire he has been unusually successfu in identifying and tracing various zones in the Carboniferous limestone. His work in Yorkshire makes the selection of him as president of the county society very appropriate, and will doubtless result in increased attention being paid to the geological problems of the Carboniferous period by the members of the union.

THE gold medal of the Institution of Mining and Metallurgy has been awarded to Sir Archibald Geikie, K.C.B., F.R.S., in recognition of his services to geological science. The Consolidated Gold Fields of South Africa gold medal and premium has been awarded to Dr. T. K. Rose for his researches on the metallurgy of gold.

THE programme of the arrangements for the new session of the Society of Arts which has just been issued includes a series of six lectures on industrial hygiene by different experts, who will deal with such subjects as dust in factories and in mines, lead and mercury poisoning in pottery and match-making, work in compressed air, and child labour. A course of lectures on the "Navigation of the Air" is to be given under the Shaw trust by Dr. Hele Shaw, F.R.S. Four courses of Cantor lectures are announced, the first on the microscope, by Mr. Conrad

NO. I986, VOL. 77]
Beck. There is a very full list of papers for the ordinary and sectional meetings, and at Christmas Mr. Martin Duncan will lecture to a juvenile audience on the kinematograph.

Dr. Koch, who returned to Berlin early this month after an absence of eighteen months in German East Africa, has been promoted to the rank of Wirklicher Geheimer Rath, with the title of Excellency, in recognition of his researches into the causes of the sleeping sickness.

AT the meeting of the London Mathematical Society on November 14, the council and officers for the ensuing session were elected as follows:-President, Prof. W. Burnside; vice-presidents,. Prof. A. R. Forsyth and Prof. H. M. Macdonald; treasurer, Prof. J. Larmor ; secretaries, Prof. A. E. H. Love and Mr. J. H. Grace; other members of the council, Dr. H. F. Baker, Mr. A. Berry, Mr. 'T. J. I'A. Bromwich, Mr. A. L. Dixon, Prof. E. B. Elliott, Mr. G. H. Hardy, Dr. E. W. Hobson, Sir W. D. Niven, Mr. H. W. Richmond, and Mr. A. E. Western.

The Times correspondent at Paris gives in the issue of November 14 particulars of an improvement of wireless telegraphy apparatus on board French warships which has enabled communication to be made with facility at a distance of $75^{\circ}$ kilometres $(466$ miles), while the previous maximum distance was 300 kilometres (186 miles). According to a telegram from Algiers, the cruiser République, on leaving Toulon, proceeded to Ajaccio, a port chosen in order to increase the difficulties of transmission to the Jules Ferry, anchored at Toulon, Ajaccio being situated in a hollow of the mountains. Communication was maintained without interruption between the two ships while the République was en route. It is also stated that the République has been able to communicate with the Eiffel Tower in Paris from the Golfe de Jouan, in the Alpes Maritimes Department, a distance of 800 kilonretres (500 miles), the ship not merely receiving messages from the tower, but communicating with it in reply.

A promising career has been cut short by the death, on November I2, of Dr. A. M. Pirrie, at the early age of twenty-eight. Dr. Pirrie went to the Sudan in roof as anthropologist to the Wellcome Research Laboratories at the Gordon Memorial College, Khartoum. Under the direction of Dr. Balfour, the director of the laboratories, he made his first expedition up the Nile to the southern limits of the Sudan, and penetrated to remote parts of the Bahr-el-Ghazal. A second expedition took him to the borders of Abyssinia. On both occasions he was engaged on anthropological and pliysiological researches into tropical diseases; but unfortunately he contracted fever, and was compelled to return to England. Dr. Pirrie brought back a valuable collection of objects of anthropological and other scientific interest, and at intervals during his illness he was engaged on his report to the Carnegie Institution and the Wellcome Research Laboratories, Khartoum, for which institutions he acted jointly in the work he carried out in the Sudan.

THE sixth annual meeting of the South African Association for the Advancement of Science will be held at Grahamstown during the week ending July II, 1908, under the presidency of the Hon. Sir Walter Hely-Hutchinson, G.C.M.G. The presidents of the sections are as follows:Section A, mathematics, physics, astronomy, meteorology geodesy, and geography, Prof. Alexander Ogg, of Rhodes University College, Grahamstown; Sections B and C chemistry, metallurgy, mineralogy and geology, engincer 